16. Монтанари М. Голод и изобилие. История питания в Европе. СПб.: Изд-во «Александрия», 2009. 279 c.

17. Гизо Ф. История цивилизации во Франции. М.: Издательский дом «Рубежи XXI», 2006. В 4-х т.

18. Пиренн А. Средневековые города Бельгии. СПб.: Изд-во «Евразия, 2001. 512 с.
19. Мулен Л. Повседневная жизнь средневековых монахов Западной Европы (X-XV века). М.: Изд-во «Молодая гвардия», 2002. 352 с.

20. Старостин Д.Н. Между Средиземноморьем и варварским пограничьем: генезис и трансформация представлений о власти в королевстве франков. М.СПб.: Центр гуманитарных инициатив, 2017. 224 с.

\title{
THE DAILY LIFE OF FRANKS ACCORDING TO WRITTEN SOURCES AT THE TIME OF GREGORY OF TOURS: CLOTHING, MILITARY AFFAIRS, URBAN LIFE AND CUSTOMS
} (C) 2019

Kazakov Igor Valentinovich, candidate of historical sciences, associate professor of World History, Law and Methods of Teaching Department Samara State University of Social Sciences and Education (Samara, Russian Federation)

Abstract. This paper is a logical continuation of our paper «The daily life of Franks according to written sources at the time of Gregory of Tours, I: diseases, medicine, hygiene and food». This paper is an attempt to collect and systematize information about the material conditions of life in the Frankish state of the Merovingians in the $6^{\text {th }}$ century in the descriptions of contemporary authors. The choice of the topic is due to the need to compose a complete picture of a person's life from the beginning of the early Middle Ages, which until now has remained poorly researched, unlike the Carolingian period. The sources used are the writings of Gregory of Tours, Venantius Fortunatus, Apollinaris Sidonius, The Chronicle of Fredegar, «The History Book of the Franks» and others. The paper collects data on the clothes of various population groups, on the weapons and armor of the Franks and the level of military affairs development, on cities and urban life, and some features of the mentality of so far half barbaric society. The collected material allows us to state that: a) the sources of the early Merovingian period, in contrast to the Carolingian era, are distinguished by the extreme scarcity of data in the field of genesis; b) despite a rather primitive look of clothing, it possessed considerable material value, as well as it had a significant essence, c) Roman cities continued to exist on the territory of Gallia, but largely lost their urban character, turning into fortified centers, and c) Christianization had very little influence on the moral character of the Franks; society remained largely barbaric, although some features indicate the beginning of the formation of a new civilization.

Keywords: Merovingians; Gregory of Tours; Fredegar; Venantius Fortunatus; The History Book of the Franks; daily life; Frankish state; early Middle Ages; clothes; weapons; warfare; early medieval city; urban life; food in Middle Ages; The Salic law; material conditions; VI century.

$$
* * *
$$

УДК 94(47).04

DOI 10.24411/2309-4370-2019-14209

Статья поступила в редакцию 05.09.2019

\section{КРЕПОСТНОЕ СТРОИТЕЛЬСТВО НА ЮГО-ВОСТОКЕ ЕВРОПЕЙСКОЙ РОССИИ В КОНЦЕ XVI - НАЧАЛЕ XVII ВЕКА}

(C) 2019

Дубман Эдуард Лейбович, доктор исторических наук, профессор кафедры российской истории Самарский национальный исследовательский университет имени академика С.П. Королёва (2. Самара, Российская Федерация)

Аннотащия. В статье рассмотрены особенности начального этапа развития волжских крепостей-городов (Самары, Саратова и Царицына), построенных во второй половине 1580-х гг. князем Г.О. Засекиным. Поставлена задача рассмотреть процесс формирования их градостроительного облика, оборонительных сооружений и состава жителей в конце XVI - начале XVII в. Источниковую базу исследования составляют архивные и опубликованные нарративные, актовые и прочие источники. Использован широкий круг исследований, в основном последних десятилетий. Сделан вывод, что вплоть до завершения Смутного времени население волжских городов-крепостей состояло из служилых людей и членов их семей. Рассматриваемые поселения выполняли как военную, так и торгово-промышленную функции на волжском пути, но фактически все они являлись крепостями. Их гарнизоны в основном снабжались государевым «хлебным и денежным жалованьем» и не имели возможности обеспечивать себя за счет промысловых и других занятий. События Смутного времени способствовали глубокому кризису в жизни волжских городов, гибели Саратова и Царицына. Только после завершения Смуты происходит их восстановление и обустройство в них посадского населения, становление новой системы укреплений.

Ключевые слова: Юго-Восток Европейской России; Волга; Самара; Царицын; Саратов; города-крепости; остроги; Смутное время; воеводы; военные гарнизоны; служилые люди; стрельцы; продовольственное обеспечение; посадское население; кремль-детинец; слободы; монахи-кармелиты; Федот Котов; голштинское посольство; Адам Олеарий. 
В последние десятилетия XVI - начале XVII в. московское правительство приступило к интенсивному освоению плодородной лесостепи Европейского Юга и Юго-Востока. В извечной борьбе «земледельческого леса» и «кочевой степи», по образному выражению С.М. Соловьева, начинает побеждать «лес» [1, с. 45]. Для того чтобы освоить эту, проецируя слова И.С. Пересветова на всю лесостепную зону Европейской России, «подрайскую землицу» [2, с. 427], следовало построить города-крепости и засечные линии, обеспечить безопасность труда земледельца, дать ему возможность заселить новые территории.

Неудачное завершение Ливонской войны, воцарение Федора Иоанновича и утверждение правительства Бориса Годунова - Андрея Щелкалова привели к изменениям в государственной политике на южных, юго-восточных и восточных рубежах страны. Особое внимание было уделено укреплению безопасности на этих направлениях, расширению пояса пограничных крепостей с последующим хозяйственным освоением пространства Поля.

В сохранившихся законодательных актах практически не удается обнаружить основные направления новой политики. Но поворот в ней был замечен и в обобщенном виде изложен в ряде нарративных, прежде всего летописных, источников. Историки широко используют данные, приводимые составителями «Пискаревского летописца» [3, с. 195], «Нового летописца» $[4$, с. $34,36,43,45-46]$ и ряда других аналогичных источников [5, с. 69-70, 104; 6, с. 98; 7, c. $244 ; 8$, c. $230-231]$.

Одним из важнейших направлений в этом колонизационном процессе было юго-восточное. Правительство осознавало особую значимость волжского судоходного пути и всей территории между Волгой и Яиком (р. Урал), вплоть до северного побережья Каспийского моря и восточного Предкавказья. Разместив военные гарнизоны только в Казанском крае и Астрахани, Москва не имела возможности контролировать все, казалось бы, уже присоединенное пространство. «Плавные рати» и «летовавшие» в «опасных» местах отряды стрельцов и казаков не могли закрепить среднюю и нижнюю Волгу, сделать ее безопасной для судоходства и промыслового рыболовства.

Идея строительства городов-крепостей по Волге между Казанью и Астраханью появилась еще в середине 1550-х гг., сразу же после присоединения Астраханского ханства [9, с. 30-35], но для ее окончательной реализации потребовалось несколько десятков лет. Судя по материалам «Ногайских дел», хранящихся в Российском государственном архиве древних актов и частично опубликованных П.П. Пекарским, только после завершения Ливонской войны правительство в 1584-1585 гг. разработало проект глубокого охвата ногайских летних кочевий 4 городами-крепостями: на Увеке (рядом с совр. Саратовом), в Самарском урочище, на притоке Камы - Белой и на впадающей в нее р. Уфе $[10$, с. 8-9, 18-21, 24]. В 1586 г. были построены лишь Самара и Уфа. Затем этот «проект» расширили и несколько скорректировали. Было принято решение защитить прежде всего ближние подступы к Астрахани как по Волге, так и по северному побережью Каспия. В 1589 г. основали Царицын, а в 1590 г. - Саратов. Руководил возведением всех трех волжских крепостей князь Г.О. Засекин [11, с. 73-96, 109-122]. В конце 1590-х гг. предполагалось построить на Волге еще один город, о чем свидетельствуют запись в делах Посольского приказа: «Чертеж Черново Яру, что меж Астарахани и Царицына при царе Борисе хотели на Волге ставити город для промыслу над воровскими казаки» [12, с. 414]. Несомненно, что закрепление России на Европейском Юго-Востоке после завершения Ливонской войны было более масштабным. Достаточно вспомнить сооружение ряда городков во главе с Терками на Тереке, а также первые попытки в середине 1590-х гг. закрепления за Россией низовьев Яика, когда в 1595 г. по просьбе ногайских мурз в устье реки был поставлен деревянный городок, срубы для которого заготовили в районе Тетюшей. Правда, просуществовал он недолго и вскоре был снесен [13, c. $493-494,504 ; 14 ; 15$, с. 190]. Таким образом, именно в конце XVI столетия в Москве сложился план окончательного закрепления Северного Прикаспия и волжского пути за Россией.

О том, как стремительно, в течение нескольких недель, строились основные оборонительные сооружения каждого из таких городов, не однажды писали исследователи [16, с. 120; 17, с. 151]. Мы не будем специально останавливаться на этом вопросе. Здесь же рассмотрим их градостроительные особенности и специфику складывания жителей в конце XVI начале XVII в., то есть в тот период, когда они фактически являлись крепостями с исключительно военизированным населением. При этом в административно-государственном делопроизводстве и в бытовой лексике изучаемого периода их традиционно именовали «городами».

Трудности в изучении начального периода существования Самары, Царицына и Саратова состоят, прежде всего, в том, что документов по их истории практически не сохранилось. Очевидно, что все они возводились по типовым проектам, создаваемым в Разрядном приказе. Изучение начального облика этих городов-крепостей осложняется еще и тем, что Саратов и Царицын были сожжены в годы Смуты и заново отстроены в середине 1610-х гг. К тому же их перенесли на другие места. Все это радикально изменило градостроительный облик и фортификационные особенности.

И все же фрагментарные данные о том, что они собой представляли в конце XVI - начале XVII в., введены в научный оборот. Об этом дают представление материалы русских и иностранных посольств, описания путешественников, актовые материалы и т.д. Очевидно, что через несколько лет после основания гарнизоны, состоявшие из годовальщиков, были заменены поселенными на постоянной основе служилыми людьми по прибору и отечеству. Воеводы и другие начальные люди расселялись в кремледетинце, а большинство с семьями в слободах, защищенных острогом.

Можно предположить, что острожные укрепления возводились только после того, когда складывался постоянный гарнизон крепости из служилых людей по прибору и отечеству. Их дома и дворовые строения в слободах необходимо было защитить дополнительной системой обороны. Так, в описании штурма Царицына войсками Шереметева осенью 1607 г. говорилось: «... город и острог взяли и государевых изменников Царицынских людей и их жон и детей побили и поимали...» [18, с. 171]. Несомненно, 
что здесь речь шла о служилых людях города и их семьях, а не о посадских жителях.

По сути, Самара, Саратов и Царицын вплоть до завершения Смутного времени являлись военными поселениями, хотя, возможно, небольшие группы посадского населения возникали в них уже в конце XVI - начале XVII в. Очевидно также, что в волжских городах оставалось зимовать какое-то количество работных людей, не успевших вернуться домой после завершения навигации, рыбных и других промыслов [19, с. 417-424].

Проплывавшие по Волге в 1599 г. Хуан Персидский (Орудж-бек Баят) и в 1603 г. С. Какаш и Г. Тектандер оставили в своих записках только перечень этих городов без какого-либо описания их [20, c. 30]. Монахи-кармелиты, спускавшиеся от Казани к Астрахани летом 1606 г., отметили, что ниже устья Камы по всей реке «только время от времени можно было встретить несколько жалких поселений, жителями которых являлись в основном солдаты да приговоренные к ссылке». Таковыми им показались Самара, Саратов и Царицын. Вынужденные провести зиму 1606-1607 гг. в Царицыне, путешественники на себе ощутили все сложности жизни в одном из подобных «жалких поселений» и дали ему весьма красочную негативную характеристику: «Царицын был тогда малозначительным городом... В нем насчитывалось немного более сотни домов. Была там однако крепость, но она... казалась более пригодной содержать мародеров, чем оказывать сопротивление корпусу регулярных войск» [21, с. 117-118]. Сами монахи смогли устроиться на одном из дворов «в остроге». То же самое можно говорить и о Саратове зимой 1606-1607 гг., когда иранского посла и «дворян шаховых» местный воевода Г.Ф. Елизаров поселил «в остроге на лутчих дворех» [22, с. 117].

В источниках рассматриваемого периода содержится крайне мало сведений и составе населения новых городов. В переписке, связанной с размещением иранского и русского посольств в Саратове при том же воеводе Елизарове, упоминаются дети боярские, стрельцы, «жилецкие люди» и «немцы» (?) [22, с. 61, 120]. В «Дневнике» Яна Сапеги содержится свидетельство о присяге в 1609 г. Лжедмитрию II саратовских детей боярских, посадских людей и «саратовского уездного мира» [23, с. 94-97; 24, с. 238]. Несомненно, что при составлении перечня присягавших саратовцев был использован стереотипный оборот речи. Общеизвестно, что Саратов в XVII - начале XVIII в. не имел своего уезда. Непонятно, почему среди присягавших не упомянуты приборные люди, составлявшие основное население крепости. Наконец, в городе не проживала сколько-нибудь значимая группа посадских людей. Нельзя не согласиться с сомнениями, высказанными по поводу этого текста А.А. Гераклитовым и другими исследователями [25, с. 195-196].

Воевода Д.П. Лопата-Пожарский в 1614 г. также не увидел в Самаре посадских людей. Приведем его слова о тех, кто жил в городе и каково было их положение: «В Самарском служилые люди и всякие ружники и оброчники бедны и голодны» [26, с. 420, $423,426-428]$. К оброчникам воевода, очевидно, относил людей, занимавшихся различными промыслами и зазимовавшими в Самаре. Несомненно, что Самара, Царицын и Саратов практически не имели посадской общины. И.О. Тюменцев совершенно опре- деленно считает, что лежащий ниже по Волге Царицын был в это время «чисто военным поселением» [27, с. 141]. То же самое мы можем сказать по поводу Самары и Саратова.

Служилые люди и члены их семей таких «военных поселений» жили в основном за счет денежного и хлебного жалованья. Составлявшие основу гарнизонов волжских городов стрельцы, пушкари и другие приборные люди, как могли, пытались поправить свое материальное положение. Но времени и сил на дополнительные промыслы в первый, самый сложный период их пребывания в пограничных городахкрепостях, не хватало. Так, осенью 1586 г. самарские приборные люди не смогли обеспечить сопровождение каравана судов по Волге, потому что «ставили на Самаре город и живучи проелись и запасу у них не стало» [28, ф. 127, оп. 1, д. 13, 1586 г., л. 65-66].

Нередко в волжских городах оставались зимовать посольские и купеческие караваны, не успевшие дойти до Астрахани или Казани до начала ледостава. Такое, например, случилось в только что построенной Самаре зимой 1586-1587 гг. [29, ф. 127, оп. 1, д. 1, 1587 г., л. 5; 30, с. 858-859]. Наиболее красочную картину подобной зимовки дают материалы по Саратову в 1600-1601 гг. Население города оказалось в крайне сложной ситуации, пытаясь прокормить казанских стрельцов, сопровождавших караван, русских и иранских послов, а также купцов, общей численностью около 200 чел. Суда с провиантом, на которых они плыли, затонули за несколько верст до города. Все заботы об обеспечении продовольствием потерпевших бедствие людей легла на плечи городских властей. В распоряжении воеводы Г.Ф. Елизарова были определенные денежные средства, а также запасы ржаной муки и овсяной крупы в государевых житницах. У «немцев» (?), стрельцов и «у всяких жилецких людей» на подворьях имелись коровы, быки, козы и куры. Выполняя поручение из Москвы, в съезжей избе составили особую перепись скота и птицы по дворам саратовских жителей. Странно, что в ней совсем не был указаны овцы (бараны) и свиньи. Воевода сообщал, что к февралю в городе осталось в наличии 150 коз и 300 кур (по данным из других источников насчитывалось около 1000) [22, с. 117-119, 129-132]. В достатке была лишь волжская рыба, а в урочища под Саратовом были разосланы стрельцы-«камышники» охотиться на лосей. Не хватало меду, но в городском кабаке варили пиво, которое также отправляли послам и их людям [22, c. 114-143]. Таковой представляется обеспеченность жителей маленького пограничного города скотом и птицей.

События Смутного времени привели волжские города в совершенное разорение. Из них сохранилась только одна Самара, но и та в совершенно плачевном состоянии. Указанный выше воевода Д.П. ЛопатаПожарский сообщал в Москву зимой 1614 г., что в Самаре не осталось запасов хлеба, приборные люди и их семьи ниществуют: «... А для осадново времени, государь, сомарским всяким людям сидети будет нечим: в твоих государевых житницах хлебных запасов для осадново времени нет; а многия, государь, стрельцы нужны (бедны - Э.Д.), и стрелетцкие жены и дети по миру ходят. А служилые, государь, люди топеря з голоду розно не брядут: держит их зимней путь; а на весну, государь удержати их з голоду будет не мочно, разбредутца розно...» [22, с. 229-230]. 
Дубман Э.Л.

Крепостное строительство на Юго-Востоке Европейской России..

Исторические науки и археология

Ситуация усугублялась еще и тем, что в городе оказались стрельцы из разоренного Саратова. По данным окладной книги 1612/13 г., в Самаре помимо «своих» 50 конных и 250 пеших стрельцов находилось еще 75 конных и 205 пеших саратовских [22, c. 241]. Как удалось расселить и прокормить такое количество служилых людей, непонятно. По словам того же воеводы, самарские и саратовские стрельцы «... бедны и наги, ходят в серых зипунах, а саратовские, государь, стрельцы разорены. А самарских, государь, конных стрельцов только пятьдесят человек; а саратовские, государь, стрельцы конные пеши; а сукон, государь, в Самарском нет, окромя денег, что в твоей государеве казне». Кстати, как и впредь в Саратове в Самаре не осталось «... яловиц и баранов и курят» $[22$, с. 220]. Очевидно, что Лопата-Пожарский не слишком преувеличил бедственное положение городских жителей.

После завершения Смуты из 3-х волжских городов лишь одна Самара сохранила своей первоначальный градостроительный облик. Уникальность состоит в том, что длительное время ее крепостьдетинец практически не менялся. Самарский кремль сохранил свои основные конструктивные особенности вплоть до начала XVIII в. Только в 1703 г. он вместе с частью посада и слобод практически полностью выгорел и его решили не восстанавливать. Новая земляная крепость была выстроена примерно в 200 м восточнее старой, за пределами основной обжитой территории Самары [31, с. 147-167].

C середины второго десятилетия XVII в. начинаются разительные изменения в облике и составе населения «малых» волжских городов. Восстанавливаются Царицын и Саратов. В Самаре появляется посад, а несколько позднее город становится уездным. По сводным данным 3-й пятины 1616 г., с его занимающихся промыслами и торговлей жителей было собрано около 700 рублей [32, с. 161]. Учитывая, что служилые людей местного гарнизона после Смуты было разорены и в городе практически не имелось крупных собственников, занимавшихся предпринимательской деятельностью, большую часть пятинных денег должны были заплатить именно посадские люди. Впервые они упоминаются в челобитной 1626 г., когда посадское население во главе со старостой «Куземкой Щепкиным» отказалось брать на себя обязательства по управлению казенным кабаком [33, л. 20]. Характерно, что в материалах 3-й пятины Саратов и Царицын не упоминаются.

Объективная картина состояния городского, прежде всего посадского, населения Самары в первой половине 1630-х гг. выявляется при изучении пятины 1634 г. [34, ф. 396 , оп. 1, ч. 26, д. 41162; 35 , c. 322-331, 506-507]. В окладной росписи указаны 69 посадских людей (имеется в виду взрослое мужское население, скорее всего, дворовладельцы или, в крайнем случае, главы семей), 22 захребетника, 9 гулящих людей, 4 жителя Рыбной слободы, 5 казенных кирпичников. К ним следует прибавить два посадских двора, которыми владели после смерти своих мужей вдовы, семьи казанского иконника и свияжского «жильца». Кроме того, отдельно были учтены калачницы, хлебницы и молочницы, к числу которых, видимо, принадлежали дворовладелицы-вдовы. Пятину платили также троицкий пономарь, никольский дьякон, игумен, братия и черный поп самарского Спасо-Преображенского монастыря. Данные пя- тины не позволяют судить об источниках формирования городского населения, но вместе со служилыми людьми (преимущественно приборными), юртовыми казаками и т.д. количество городских жителей представляется для того времени весьма значительным. По самым предварительным подсчетам, в городе, кроме семей гарнизона (с общей численностью до 2500-3000 мужчин и женщин), насчитывалось около 1000 человек обоего пола, преимущественно посадского населения. Среди городов-крепостей, располагавшихся по Волге от Казани до Астрахани, Самара в это время была самым крупным населенным пунктом. К примеру, в Саратове в 1634 г. насчитывалось 32 посадских двора (или семьи) и 51 семья соседей и подсоседников, которые вкупе заплатили всего 121,71 руб. пятинных денег [36, с. I-XXIII].

Однако, как это показывают более поздние материалы, Самара, Саратов и Царицын не смогли стать в XVII в. крупными посадскими центрами. П.П. Смирнов справедливо писал, что одним из факторов задержки развития «и даже "разрушения" посадских центров Казанского Дворца была "милитаризация границы"» [37, с. 65].

Представление о Самаре и ее крепости в 1620-е 1630-е гг. дают, прежде всего, описания и рисунки западноевропейцев и русских путешественников. Попытку восстановить облик города через восприятие внимательных наблюдателей того времени не однажды предпринимали местные краеведы (Е.Ф. Гурьянов, А.К. Ширманов и другие). Но, как правило, их реконструкции содержат ряд неточностей, и поэтому мы вновь вынуждены обратиться к данной теме.

Первое описание облика города в 1623 г. оставил спускавшийся вниз по Волге купец Федот Котов. Известны несколько списков его сочинения. Но только в одном, обнаруженном и опубликованном Н.М. Петровским, имеются сведения о Самаре. Позднее, видимо, лист с этим описанием был утрачен. Поэтому некоторые исследователи высказывают сомнения в достоверности его публикации. На наш взгляд, Петровский действительно работал с данным текстом, о чем свидетельствует необычайная реалистичность и точность описания. Приведем его полностью: «Город Самара стоит на луговой стороне, от Волги песок залег, а город стар, рубленой, низок, и острог по тому же городовому месту. А под городом река Самара течет и[з] степи, устье под городом пало в Волгу, по нижнюю сторону города, а над рекою бани, а посады и ряды в городе, а около степь» [38, с. 291-292].

Город Самара, по сравнению с недавно восстановленными Саратовом и Царицыным, ко времени плавания Котова был действительно уже «старым». Есть еще ряд крайне важных деталей в публикации Петровского, а именно: «город... рубленой, низок, и острог по тому же городовому месту». «Город» здесь - это кремль, крепость, в отличие от «острога» - второй системы укреплений, защищающей от нападений посад с его торгово-промышленным населением и слободы стрельцов. Понятие «рубленый» город является синонимом «города венчатого», в отличие от стоялого острога. В обобщающем исследовании о средневековом русском градостроительстве говорится: «В случае стоячего острога городовая стена, невзирая на ее значительную протяженность по горизонтали, приобретала выраженную вертикальную направленность за счет вертикально поставленных бревен с заостренными концами; рубленая же стена, 
более спокойная, с сильно подчеркнутой горизонталью, теснее увязывалась с рублеными башнями, которые становились единственными носителями вертикального начала» [39, с. 76].

К сожалению, более конкретные сведения об устройстве рубленых (где бревна были уложены, как в современных бревенчатых домах) стен самарского кремля отсутствуют. Неясно, какими они были - однорядными, двухрядными в виде тарас и т.д.? Важно, что при характеристике вновь отстроенных, располагавшихся на луговом (левом) берегу Волги Саратова и на высоком (правом) берегу Царицына Котов указал только соответственно «стоячий острог» и «невысокий тын», а также «круглые» (?) бревенчатые рубленые башни. Какой облик имела в этих городах сама крепость, неизвестно. Котов, несомненно, ошибся по поводу «круглых» башен, так как они возводились только в каменных крепостях.

Интересную смысловую нагрузку приобретает еще одна характеристика Самары: «город... низок». Ясно, что рубленые стены крепости, стоявшей на возвышенности, с Волги выглядели низкими. Острог, по Котову, стоял «по тому же городовому месту», а посады и ряды были в «городе». За пределами крепости оказались только бани. Действительно, бани и кузницы ставили за пределами тесно застроенной городской территории, так как опасались пожаров.

Именно такой же монолитной, закрытой со всех сторон системой деревянных укреплений, увидел Самару в конце лета 1636 г., через 13 лет после поездки Котова, голштинец Адам Олеарий. Помимо описания, он первым сделал рисунки волжских городов. Эти изображения используются в большинстве изданий, посвященных ранней истории Самары, Саратова и Царицына. Как правило, исследователи подчеркивают высокую информативность и достоверность «городовых» описаний и рисунков А. Олеария. Однако некоторые историки правомерно считают, что в ряде случаев выдающийся европейский энциклопедист мог допустить погрешности [40, с. 112-114]. В частности, есть причины усомниться в достоверности А. Олеария и в нашем случае [41, c. 24-28]. Голштинец увидел в Самаре, Саратове, Царицыне и Черном Яру только населенные стрельцами военные пункты, что не подтверждают другие источники 1630-х - 1640-х гг. На его рисунке в Самаре отсутствуют слободы и предместья; в Саратове же, как сообщает голштинец, «живут одни лишь стрельцы». Нас в большей степени интересует Самара, которую он обрисовал буквально одним предложением: «Этот город лежит по левую руку, в 2-х верстах от берега, построен в виде четырехугольника, имеет небольшое количество каменных церквей и монастырей». Однако по другим свидетельствам XVII - начала XVIII в., Самара не была так удалена от берега Волги. Да и каменные храмы появились в ней позднее. Все жилое пространство города на рисунке Олеария было огорожено «стоячим» острогом, а очертания внутренних укреплений кремля не просматриваются. Но, по данным пятины 1634 г., переписным книгам 1646 г. и другим документам, рядом с укреплениями, за пределами «города» и острога, располагались слободы [42, с. 87-90]. Олеарий пишет о р. Самаре, на которой стоял город, но на рисунке ее не указывает.

Думается, что основная причина этих погрешностей состоит в том, что судно с голштинским по- сольством проплыло мимо города вниз по Волге в августе (28 по старому стилю), в самый межень, вода стояла низко, потому-то путешественник и указал, что Самара стояла так далеко от волжского уреза. Кроме того, судно шло вдоль правого, дальнего берега, рано утром, и сам Олеарий писал, что ему не удалось хорошо рассмотреть город.

Рисунок (гравюру) Самары историки обычно используют из русского издания книги А. Олеария, подготовленного А.М. Ловягиным в 1906 г. [43, c. 368-369, 388]. Иллюстрации для него взяты из 2-х первых западноевропейских изданий книги 1647 и 1656 гг., гравюры для которых полностью повторяют рисунок Олеария и делались под его контролем. Но известен и другой рисунок Самары из европейского издания «Путешествия...» А. Олеария начала XVIII в. [44, s. 429-430]. На первый взгляд, он существенно отличается от «классического» изображения как элементами пейзажа, окружающего крепость, всадниками, повозками и путником на первом плане, так и конфигурацией города, вытянутого по волжскому склону. Но при внимательном рассмотрении деталей крепости: башен, внутренней застройки - мы видим ту же самую Самару. На этом рисунке четко видно, что скопление приходских и монастырских храмов находилось в юго-восточной части огороженного острогом пространства, там, где, видимо, на крутом берегу р. Самары находился рубленый кремль. Каких-либо деталей его оборонительных сооружений ни на первом, ни на втором рисунках найти не удается. Странно, что у Олеария в обоих случаях отсутствует угловая юго-восточная башня, базовая при защите города от нападений кочевников.

Мы не будем специально рассматривать посадское расселение и наличие слобод в Самаре и других городах. Эта тема традиционно является предметом изучения региональных историков, и новое обращение к ней вряд ли необходимо.

Таковой представляется история 3-х волжских городов в конце XVI - начале XVII в., которые на этапе своего начального формирования фактически являлись крепостями с исключительно военным гарнизоном на великом волжском пути.

\section{Список литературы:}

1. Соловьев С.М. Сочинения. В 18 кн. Кн. VII. Т. 13-14. История России с древнейших времен. М.: Мысль, 1991. 701 с.

2. Пересветов И.С. Большая челобитная // Памятники общественной мысли Древней Руси: В 3-х т. Т. 3: Московская Русь / сост., автор вступ. ст. и коммент. И.Н. Данилевский. М.: РОССПЭН, 2010. C. $416-428$.

3. Пискаревский летописец // Полное собрание русских летописей. Т. 34. М.: Наука, 1978. С. 31-220.

4. Новый летописец // Полное собрание русских летописей. Т. 14. 1-я половина. СПб.: Типография М.А. Александрова, 1910. С. 23-154.

5. Солодкин Я.Г. Очерки по истории общерусского летописания конца XVI - первой трети XVII веков. Нижневартовск: Изд-во Нижневарт. гуманит. ун-та, 2008. $237 \mathrm{c}$.

6. Хазанова С.И. Пискаревский летописец: Происхождение, источники, авторства. М.: Квадрига, 2014. $176 \mathrm{c}$.

7. Тихомиров М.Н. Пискаревский летописец как исторический источник о событиях XVI - начала 
XVI вв. // Тихомиров М.Н. Русское летописание. М.: Наука, 1979. С. 232-247.

8. Тихомиров М.Н. Малоизвестные летописные памятники XVI в. // Тихомиров М.Н. Русское летописание. М.: Наука, 1979. С. 220-231.

9. Дубман Э.Л. Вопрос о сооружении русских городов на Волге в московско-ногайских взаимоотношениях середины 1550-х гг. // Вестник СамГУ. 2012. № 2/2. (93). С. 30-35.

10. Пекарский П.П. Когда и для чего основаны города Уфа и Самара? СПб.: Тип. императорской академии наук, $1872.30 \mathrm{c}$.

11. Дубман Э.Л. О князе, который строил города (жизнь и деятельность князя Григория Засекина): монография. Самара: Изд-во СамНЦ, 2018. 158 с.

12. Опись архива Посольского приказа 1626 года Ч. 1 / подгот. В.И. Гальцов. М.: Главное архивное управление при СМ СССР, 1977. 421 с.

13. Разрядная книга 1475-1598 гг. М.: Наука, 1966. $617 \mathrm{c}$.

14. Отдел рукописей Российской национальной библиотеки. Ф. 885. Эрм. 390/1.

15. Дариенко В.Н. Основание города Гурьева // Вопросы истории: сб. ст. Вып. V. Алма-Ата: Каз. гос. ун-т им. С.М. Кирова, 1973. С. 189-197.

16. Косточкин В.В. Из истории русского сборного строительства XVI в. (Новые данные о полоцких крепостях времени Ивана Грозного) // Архитектурное наследство. 1969. № 18. С. 118-124.

17. Перхавко В.Б. Государев дьяк Иван Выродков // Вопросы истории. 2009. № 7. С. 150-154.

18. Смутное время Московского государства. 1604-1613 гг.: М.: Имп. о-во истории и древностей рос. при Моск. ун-те, 1910-1918. Вып. 2: Акты времени правления царя Василия Шуйского. (1606 г. 19 мая - 17 июля 1610 г.) / Собрал и редактировал А.М. Гневушев. $1918.421 \mathrm{c}$.

19. Кушева Е.Н. Сказки Генерального двора как источник истории городов Поволжья на рубеже XVII-XVIII вв. // Города феодальной России: сб. ст. памяти Н.В. Устюгова. М.: Наука, 1966. С. 417-424.

20. Царицын в путевых записках, дневниках и мемуарах современников (конец XVI - 1917 г.). Т. 4 / под общ. ред. проф. М.М. Загорулько. Волгоград: Волгоградское научное издательство, 2005. 394 с.

21. Магилина И.В. Посольство монахов-кармелитов в России. Смутное время глазами иностранцев. 1604-1612 гг. М.: Центрполиграф, 2018. 160 с.

22. Памятники дипломатических и торговых сношений Московской Руси с Персией. Т. 2. Царствование Бориса Годунова, Василия Шуйского и начало царствования Михаила Федоровича / изд. под ред. Н.И. Веселовского. СПб.: Товарищество паровой скоропечатни Яблонский и Перотт, 1892. 447 с.

23. Дневник Яна Петра Сапеги (1608-1611) // Памятники истории Восточной Европы. Источники XV-XVII вв. в 9 т. Т. 9 / сост. И.О. Тюменцев и др. М.; Варшава: Древлехранилище, 2012. 456 с.

24. Рабинович Я.Н. Саратов в Смутное время (1606-1614) // Изв. Сарат. ун-та. Нов. сер. Сер. История. Международные отношения. 2017. Т. 17, вып. 2. C. 228-240.

25. Гераклитов А.А. История Саратовского края в XVI-XVIII вв. Саратов: Друкарь, 1923. 381 с.

26. Акты исторические, собранные и изданные Археографическою комиссией. СПб.: Тип. II-го От- деления Собственной Е.И.В. Канцелярии, 1843. Т. 3. $538 \mathrm{c}$.

27. Тюменцев И.О. Начало Царицына: гипотезы и факты // Стрежень: Научный ежегодник. Вып. 1. Волгоград: Государственное учреждение «Издатель», 2000. С. 132-147.

28. Российский государственный архив древних актов (РГАДА). Ф. 127. ОП. 1. Д. 13. 1586 г.

29. РГАДА. Ф. 127. Оп. 1. Д. 1. 1587 г.

30. Карпов А.Б. Уральцы. Исторический очерк. Ч. 1. Яицкое войско от образования до переписи полковника Захарова (1550-1725). Уральск: Войсковая тип., 1911. $1013 \mathrm{c.}$

31. Дубман Э.Л. Земляная крепость в Самаре и другие оборонительные сооружения региона в конце XVII - начале XVIII в. // Самарский край в истории России. Вып. 5: мат. Межрегион. науч. конф., посвящ. 190-летию со дня рожд. П.В. Алабина / отв. ред. Д.А. Сташенков. Самара: Изд-во Самарского научного центра, 2015. С. 147-167.

32. Воскобойникова Н.П. К истории финансовой политики Русского государства в начале XVII века // История СССР. 1996. № 3. С. 156-161.

33. Научно-исторический архив Санкт-Петербургского института истории РАН. Ф. 38. ОП. 1. Д. 68.

34. РГАДА. Ф. 396. Оп. 1. Ч. 26. Д. 41162.

35. Карпачев А.М. Города Московского государства и их торгово-промышленное население по пятине 1634 (142) года: дис. ... канд. ист. наук. Мн., 1948.522 c.

36. Смирнов П.П. Окладная роспись пятины по городу Саратову 1634 года // Труды Саратовской учёной архивной комиссии. Саратов, 1916. Вып. 33. C. I-XXIII.

37. Смирнов П. Города Московского государства в первой половине XVII века. Т. 1, вып. 2. Количество и движение населения. Киев: Типография А.И. Гроссман, 1919. 342 с.

38. Петровский Н.М. Новый список путешествия Ф.Я. Котова // Известия Отделения Русского языка и словесности Императорской Академии наук. 1910. T. XV, кн. 4. С. 287-299.

39. Русское градостроительное искусство: Градостроительство Московского государства XVI-XVII веков / под общ. ред. Н.Ф. Гуляницкого. М.: Стройиздат, 1994. $318 \mathrm{c}$.

40. Патрушев В.С. Острог средневекового Козьмодемьянска (замечания к рисунку Адама Олеария) // Средневековая археология Волго-Уралья: сб. науч. тр. к 65-летнему юбилею д.и.н., проф., член-корр. АН РТ Ф.Ш. Хузина. Казань: Институт археологии им. А.Х. Халикова АН РТ, 2016. С. 112-116.

41. Ширманов А.К. О двух рисунках города Самары в изданиях путешествий Олеария // Краеведческие записки. Вып. 2. Куйбышев: Куйбышевское книжное издательство, 1971. С. 24-28.

42. История Самары (1586-1917 гг.): монография / под ред. П.С. Кабытова, Э.Л. Дубмана, О.Б. Леонтьевой. Самара: Издательство «Самарский университет», 2015. $480 \mathrm{c}$.

43. Олеарий А. Описание путешествия в Московию и через Московию в Персию и обратно / Введение, пер., примеч. и указатель А.М. Ловягина. СПб.: Издание А.М. Суворина, 1906. XXVIII, 582 с.

44. Olearius A. Voyages tres-curieux et tresrenommez faits en Moscovie, Tartarie et Perse. Amsterdam, 1727. S. 786. 


\title{
FORTIFICATION IN THE SOUTH-EASTERN PART OF EUROPEAN RUSSIA AT THE END OF THE XVI - BEGINNING OF THE XVII CENTURIES
}

(C) 2019

Dubman Eduard Leibovich, doctor of historical sciences, professor of Russian History Department Samara National Research University (Samara, Russian Federation)

\begin{abstract}
The paper discusses the features of the Volga city fortresses (Samara, Saratov and Tsaritsyn) development at its initial stage in the second half of the 1580s by knyaz G.O. Zasekin. The task is to consider the process of their urban planning appearance and defensive structures development as well as the composition of the inhabitants at the end of the XVI - beginning of the XVII centuries. The source base of the study is archival and published narrative, acts and other sources. A wide range of studies have been used, mainly in recent decades. It is concluded that until the end of the Time of Troubles, the population of the Volga fortress cities consisted of service people and members of their families. The settlements performed both military and commercial functions on the Volga route, but in fact, all of them were fortresses. Their garrisons were mainly supplied by the sovereign «bread and money salary» and were not able to provide themselves through fishing and other activities. The events of the Time of Troubles contributed to a deep crisis in the life of the Volga cities, the death of Saratov and Tsaritsyn. It was only after the end of the Time of Troubles when their restoration took place and a new system of fortifications was created.

Keywords: Southeastern part of European Russia; Volga; Samara Tsaritsyn; Saratov; fortified cities; jails; Time of Troubles; governors; military garrisons; service people; archers; food supply; urban population; Kremlin-Detinets; settlements; Carmelite monks; Fedot Kotov; Holstein Embassy; Adam Olearius.
\end{abstract}

$* * *$

УДК 908

DOI 10.24411/2309-4370-2019-14210

Статья поступила в редакцию 26.07.2019

\section{САМАРСКИЙ ОБЩЕСТВЕННЫЙ ДЕЯТЕЛЬ И ДЕПУТАТ ГОСУДАРСТВЕННОЙ ДУМЫ РОССИЙСКОЙ ИМПЕРИИ В.А. ПЛЕМЯННИКОВ} (C) 2019

\author{
Елисеев Андрей Иванович, аспирант кафедры российской истории \\ Самарский национальный исследовательский университет имени академика С.П. Королёва \\ (2. Самара, Российская Федерация)
}

\begin{abstract}
Аннотация. В данной статье на основе анализа опубликованных и архивных документов, материалов периодической печати, воспоминаний современников рассмотрена общественно-политическая деятельность члена Самарской земской управы, одного из организаторов Самарского губернского и Бузулукского уездного комитетов конституционно-демократической партии, депутата Государственной Думы Российской империи первого созыва Василия Андреевича Племянникова. Прослежена работа В.А. Племянникова в земских учреждениях Самарской губернии и общероссийских земских съездах, в ходе которой он хорошо изучил положение дел в регионе, получил богатый опыт общественной деятельности и сформировал свои политические взгляды. Показаны его взаимоотношения с центральными органами власти и региональными общественными организациями. Годы первой русской революции стали вершиной его общественно-политической деятельности. В статье анализируется активное участие В.А. Племянникова в избирательной кампании по выборам в Государственную Думу и организация им местного отдела конституционно-демократической партии в Бузулукском уезде. Проведенная им большая агитационная работа и политический вес в губернии способствовали избранию Племянникова в депутаты Государственной Думы. Помимо реконструкции политической деятельности В.А. Племянникова в статье вводятся в научный оборот ранее неизвестные биографические данные.

Ключевые слова: Племянников Василий Андреевич; земские деятели; политическая биография; Государственная Дума Российской империи; Самарская губерния; Бузулукский уезд; конституционно-демократическая партия; депутаты; общественная деятельность; земские съезды; выборы в Государственную Думу; либералы.

В современной отечественной исторической науке наметился устойчивый интерес к изучению региональных политических деятелей. Внимание исследователей направлено на функционирование как определенных политических групп, так и их отдельных представителей. В связи с этим актуальным является изучение деятельности депутатов от Самарской губернии в Государственных Думах Российской империи. Рассмотрение данной проблемы позволит расширить представление о социально-политическом развитии региона, а также о взаимоотношении власти и общества. Целью данной статьи является рассмотрение общественной и политической деятельности В.А. Племянникова.

В исторической литературе представлена, в основном, информация о Племянникове как земском деятеле и депутате Государственной Думы Российской империи. Краткие биографические сведения опубликованы в дореволюционных справочных изданиях [1, с. 290; 2, c. 68; 3, с. 54], посвященных Государственной Думе, энциклопедии «Государственная дума Российской империи, 1906-1917» [4, с. 464], в «Энциклопедии Самарской области» [5, с. 183] и коллективной монографии «Самарское земство: опыт практической деятельности» [6, с. 95-96]. Некоторые сведения можно найти в работах, посвященных конституционно-демократической партии [7]. Отдельно общественно-политическая деятельность В.А. Племянникова не изучалась.
\end{abstract}

